\title{
To Investigate the Foreign Study Experience Affections in English Class: Influences on Lecturers and Students' Attitude
}

\author{
Peng Zhu ${ }^{1} \quad$ Dr. Denchai Prabjandee ${ }^{2}$ Dr. Punwalai Kewara ${ }^{3}$ \\ 1.School of Foreign Languages and Literature, Chuxiong Normal University, 546 South Lucheng Road, \\ Chuxiong 675000, China \\ 2.Lecturer, Department of International Graduate Studies in Human Resource Development, Burapha University, \\ Bangsaen 20000, Thailand \\ 3.Assistant Professor, Department of International Graduate Studies in Human Resource Development, Burapha \\ University, Bangsaen 20000, Thailand \\ * Email of the corresponding author: alex.watermelon@hotmail.com
}

\begin{abstract}
This study was attempted to define to the language learning and teaching practice of the English lecturer had been influenced by personal foreign study experience, and also the student's attitude toward the foreign study experienced lecturer in class. Since the researcher immersed into the phenomena to collect first-hand data, therefore a qualitative research was applied in this study, to assume dynamic reality initially. Totally, 6 lecturers and 9 students had interviewed in random. By analyzing the data, the outcomes of the study presented that the lecturers' English learning and teaching performance were influenced by personal study experiences at abroad in different aspects, which inspired the lecturers in teaching innovation in certain areas. And most of the students expressed positive attitude towards those lecturers who had foreign study experienced and claimed personal concerns and suggestions on these lecturers. Eventually, these impacts also contributed to the innovations in English teaching concepts, English teaching methods, and English teaching skills. Finally, findings from the students' interview also suggested practical concerns on the foreign- experienced lecturers in real teaching.
\end{abstract}

Keywords: key words, foreign study experience affection, students' attitude

DOI: $10.7176 / \mathrm{JEP} / 11-32-01$

Publication date: November $30^{\text {th }} 2020$

\section{Introduction}

Traditionally, grammatical and semantic learning has been vitally emphasized in English teaching and learning. However, with highly-developed new techniques have been implemented rapidly in our daily life, which facilitates many languages and cultures ingrate together, and been shared or transmitted in different linguistic and cultural setting, which impels language learning and teaching to be more like a global linguaculture network. Therefore, we are experiencing a prosperous language and cultural network. Due to this reason, it is important for both language lecturers and learners to practice in many different linguistic and cultural backgrounds. Depart of the grammar teaching in English, culture is also very important in English teaching as well.

As to English language lecturers, non-native English language lectures in particular, they are provided more chances to further their overseas learning to improve their English studies, training and teaching no matter in native English-speaking countries or non-native English-speaking countries. After years of study or training in English knowledge, and living in overseas for a time, gradually those language lecturers' language and cultural experience might have been affected eventually. Therefore, their linguistic and cultural experiences will also affect their teaching and students' language learning after they back to teaching to some extent.

\subsection{The problem}

As to teaching English and teaching culture in EFL classroom, traditional teaching mode generally focus on linguistic practice in both English proficiency and intercultural competence. Obviously, that intercultural or crosscultural communication is important in English teaching and learning. But recently, in which there goes a phenomenon that lecturers are not only teach English or explain cultural phenomena via English language, but also communicate linguaculture experience with students via English. Meanwhile, same to the English lectures, English learners also not only learn English or cultures via English, but also embraced their individual linguaculture experience as well. Therefore, in this study, English is considered as a lingua franca to facilitate English teaching and learning between English lecturers and learners in communication classrooms.

English teaching in most Chinese universities, no matter non- English major or English major, English is the major language in teaching and communication. Eventually, the use of English inevitably bridges the communication both in Chinese to English and also English to English as well. This teaching method might beneficial for both English learning and teaching at the outset, since English as the lingua franca which easier the communication between lectures and students, Chinese and English. However, recent studies and researches claimed that students' high proficiency in English communication does not meet the real expectations in different 
sorts of language context. For example, it is noticeable that in many aspects of 'English culture', especially the discourse patter 'English', which contents English as well as transmitted cultural discourse via English teaching and learning. Following graph illustrate my idea briefly.

By reviewing recent English teaching trends around China, it shows that grammatical and semantic learning is extensively practiced in English learning and teaching. However, with the grooming of English has been raised as a global language in virtue of rapid increasing globalization. Both students and English lecturers have realized that only grammatical and semantic knowledge teaching and learning cannot meet the needs of English as a global language. Gradually, numerous English learners and lecturers have noticed that English teaching and learning should be analyzed in relation of a cultural discourse communication. Personally, the researcher experienced language and culture learning at abroad, both in English native speaking country and English non-native speaking countries as well. And most of the collogues worked with the researcher more or less had been to abroad to further their language and culture study either. The following questions were assisted the research to explain the lecturers' affections and attitudes from the students.

1. What linguistic and culture aspects had been influenced by the lecturers' foreign study experiences?

2. How did the students reacted to these foreign study experienced lecturers in class?

3. What the students' attitude towards these foreign study experienced lecturers in class?

\section{Literature review}

In general, language learners, no matter what languages they are about to learn, no one can learn without a certain linguistic background. This linguistic background could be their born place, or foreign or second language learning sites as well (Halliday, 2003). In terms of the differences in linguistic learning content, language teachers are encouraged to vary their teaching methodology correspond to the language learners' learning behavior and language content as well. When consider on language use, or linguistic practice. Language practice in a certain social content is considered. But social content consists one of the essential aspects in language formation, to holistically view language, linguistic system, linguistic practice and linguistic resources are elements necessary (Halliday, 2003). Linguistic system neutrally exists in language, which enables language learners to achieve personal linguistic practice via sorts of linguistic resources. As to EFL learning and teaching (Pan, 2015), traditionally has consisted of grammatical competence, communicative competence, and language proficiency. However, by reviewing sorts of literature, recently most EFL teachers in China have been increasingly aware of the influences of cultural awareness from both language learners and lecturers (Pan, 2015). Therefore, linguistic practice and culture awareness in target language affects the language learner's learning consistently. In terms of the consistent learning and teaching process, language lecturers would better to arouse and inspire language learners' linguistic practice interests and also to facilitate learners' cultural awareness while learning.

\section{Research methodology}

The purpose of this research was to explore how English lecturers incorporate their linguaculture experience in their English teaching. Based on this purpose, qualitative research was legitimate as a methodological frame for this study. According to Alison (2005), qualitative research process oriented in which the researcher immersed oneself into the field to collect first-hand data, since qualitative research assumed dynamic reality. in phenomenology, the researcher was attempted to get at the essence or basic norm beneath the meaning of an experience. As to interview in phenomenology research, which was the primary method to collect data. Apart from those who were directly experience with the phenomenon, a phenomenological researcher usually explored experience or the underlying meaning of the experience. Therefore, a process, personally I named it suspension was necessary in phenomenological interview. During in the suspension process, curb from personal prejudices, perceptions, and assumptions which helped the researcher to examine various dimensions of the experience or phenomenon more authentically. Thus, to avoid influences from personal prejudice and bias, bracketing assisted the researcher to access and examine the authenticity of the experience itself.

\subsection{Participants}

Participants, in general, the number of participants in qualitative study normally focus on a certain small group (Creswell, 2007). Therefore, considering my research purpose and research methodology, to recruit target and potential participants, the scale of participants in this study had been narrowed down to those Chinese English lecturers, who was teaching courses related to English courses, at the School of Foreign Languages and Literature, Chuxiong Normal University, Yunnan Province, China.

\subsection{Data collection process}

Interview process, to collect more individual and vivid data, I was preferred a semi-structured interview. Standardized interview questions were composed under the conduct of my supervisor, and question items were open-ended to access more to the interviewees' experiences rather than me. In this study, interview was separated 
into two sections: lecturers' interview, and students' interview. Six lecturers and nine students were interviewed in total, meanwhile, interviewees were asked a set of questions, but they were free to approach the questions and answer it in any manner they like. Moreover, interview in my study was allowed or spontaneity from interviewees, while providing a fair degree of comparison between individuals, which helped me to analyze how interviewees respond to questions and achieved more systematic data analysis.

\section{Findings}

In order to analyze data be more objectively, original interview transcripts were quoted and presented in narrative way. To keep the data effectively, data analyses were presented separately to descript influential factors, which were set as the rational themes to synthesize the raw interview data. Following figure 1 illustrated the findings in general.

\section{1 impressive influential aspects}

- $\quad$ Language and culture teaching methods

By analyzing the transcription from the lecturers' interview, it could be defined that most of the lecturers explained the language learning and teaching methods that the lecturer experienced at abroad impressively. Form the quotes following. Generally, it could be categorized that the class the lecturers experienced at abroad, the class formation was mostly group by personal learning interesting, or teaching topic related. In the class, peer learning and discussion were the main teaching assists in the class which motivated the lecturers learning interested.

Impression 1: class formation

... The professor gave us time to discuss with classmates briefly...

... The language teaching class was more like a seminar, peer learning, discussing method among the students...

... they preferred to apply group learning method rather than teacher oriented...

... English lecturers were not a controller in the class, but to be a well-prepared facilitator to motivate students to improve their language competence and proficiency in their own ways...

... The teaching model was group study, and individual learning and teaching model... Impression 2: reactions and interactions in the class

... share his opinion with us, even discuss with us seriously...

... I could have chance to talk with my friends and even discuss with them and my professors...

... we were encouraged to share our outcomes with the professor and our friends...

... allowed to have my own perspectives no matter it is stable or not...

... the professor encouraged me to extend my reading and my perspectives on how to understand, how to define sorts of ideas and even how to criticize...

Impression 3: teaching method

... The professor explained the culture, religious, legends and language expressions in the vampire literatures...

... conducted us to appreciate all the aspects, and gave us comparisons in different literature format...

... conducted us to analyze the structures and writing methods, which made us not only understand literature itself, inspired us to appreciate literature work in different ways... Impression 4: varies in language material

... lecturers did not like to explain on the textbook exclusively, they had sorts of teaching methods and materials...

The lecturer was impressed by the difference in English language learning and teaching, especially the way of the foreign lecturer's teaching and guide in the class.

English teaching method that the lecturer experienced in Australia was more encouraged. As it described in the quotes that the class in there was more like a discussion between students and lecturer. The topic in the class was broad which included a comprehensive study area. The lecturer was encouraged and conducted in personal language and culture study.

- $\quad$ Language and culture learning behaviors Impression 1: Personal behavior ... we prepare before class. I think it helped the professor and us to know what was the next learning point, and we were prepared to the new class that made us understand better than before...

... the students' reading competence, they were taught with multi-level reading 
competence...

... they already fixed their habit in reading, especially in extensive reading...

... students prefer to learn individually or with friends. The class could be very flexible, the professor did not control the whole class...

... we had to make a summary on what we had learning in a day with our group members, and sometimes we had to present our own perspectives on some projects...

... We even could question our professors if we have doubts in the point, and we could discuss with each other..

Impression 2: Facility supports

... the students, the lecturers, the university and the library collaborate together, to make a reading net, an extensive reading network for all of them...

... facilitated by their modern education technology. All of these to support students learning, especially in language learning, and reading. I really appreciated...

- Cross-culture awareness and communication

... experienced the differences in English learning and teaching impressively...

... the most impressive one was my academy study which influenced by culture differences...

... I am an English language lecturer, I noticed that language learning would better to learn with culture background...

Quotes above presented the lecturer experienced impressively in the language study at abroad, especially experienced cultural differences in the academic study, which triggered the lecturer's change on the notion of English language.

- Function of English language

As most of the lecturer considered that English in practical use could be variously learned and used, which emphasized that English connect and exchange cultures inseparably (Scollon, 2012).

... English in real use, which was a connection, to link up different culture, and languages, or other field of study, but finally we can find a common part, and we understand this common part via English. I think this is the greatest thing of English... .... consider that English as a media, a bridge, or recent trend we consider that English as an international or global language as well ...

4.2 Innovated aspects

The lecturers personal linguaculture study experience triggered personal innovations in the language class. Following quotes explained the innovations, and explain the linguaculture potentials their incorporated in the class.

- Innovation 1: teaching methods and skills

Due to the influence from the abroad study experiences, most of the lecturers adjusted their English teaching after back to China.

Adjustment 1: Varies form of the class

... I practiced more open-mind perspectives to face problems in both language learning and teaching when I backed to China ...

... I try my best to give my students more original learning and teaching resources...

... helps my language class be more lively, interesting, and my teaching point was narrowed down to be more specific.

Adjustment 2: Interaction in the class

... try to encourage the students to think like an English, even language use in my teaching...

...especially in my reading class, I encourage students to talk, to share their understanding on an article...

... encourage students to interact with me in my English class...

... shared language learning materials related to our life with my students in my class, and discuss recent hot issues with them...

Adjustment 3: Facilitating and motivating in the class

... I try to give my students a language learning setting to motivate them... Language and culture parts are two important parts that I kept original in my teaching...

... I have tried to combine my language learning class model in Canada with my previous teaching model, to motivate students English learning interests...

use some recent and students-related language materials to attract my students learning interests in my class...

... apply some new language learning materials and teaching method in my English 
class...

... I have tried to use my own learning experience, in both language learning and life experience in the United Kingdome, to apply on my daily teaching at Chuxiong Normal University when I backed to China. This trying still on my progress, since I have to consider my students' proficiency and our learning background...

- Innovation 2: teaching concept

Adjustment 1: Culture study in language learning

... I have noticed my teaching can be understood better by my students right now. Especially when I have some cultural aspects in language, and literature, students turn to be more interesting in literature...

... not only focus on helping students improve their English skills, English proficiency, but also tried to lead and conduct student to be aware of the multi-function of English, such as culture function..

... our comprehension on both language and culture also will be influenced by our mother language and Chinese culture more or less...

... as a language learner and language lecturer, we have to accept that influence from our mother language and Chinese culture is really existed..

Adjustment 2: Perspective on English language

... I noticed different perspectives in English teaching, no matter it is exclusive to English as second language region, or English as foreign language area...

... I noticed that English is not only a certain subject, my English teaching was turned to be more flexible in the class...

- Innovation 3: concerns on teaching

Teaching concern explained that the lecturer considered about the practical language learning and teaching settings in real, since the students' individual English proficiency, English leering behavior, learning expectations varied individually. And also, the first language influences, learning environment had to be accounted into the influential factors as to the Chinese students. therefore, the lecturer had to balance their teaching in practical and affections of personal language and culture experiences.

... I have to consider our students' language competence, and also their reading capacity. Since our students normally focus on literature textbooks, they rarely extend their reading in different ways...

... as a Chinese lecturer, I have to consider my students learning expectations, their language proficiency, and the influences from our mother language settings, then I may adjust part of my teaching to fix my Chinese students in real...

4.3 Students' attitude and expectation

Students interview presented their expectation from the foreign- experienced lecturer, and also their personal concerns and suggestions for the lecturer in the future. Generally, by analyzing the students' interview, all the participants in the interview were interested in learning with foreign- experienced lecturer, they positively considered that the foreign- experienced lecturer would facilitate them in both English linguistic practice and crossculture communication in certain linguistic content.

- Students' attitude

... I think foreign- experienced lecturer is useful...

... I think that more helpful to study with those lecturer...

... I think if we have foreign- experienced lecturers will be better for us...

... So, I think it is good if we can have linguaculture experienced teacher to study with...

... I think it will be very interesting if we have linguaculture experienced lecturer to enjoy our class...

- Students' Expectations

Expectation 1: Facilitate in linguistic practice

some of the participants also stated that the foreign-experienced lecturer was rich in language use since they studied at the foreign countries for years. They could distinguish the English use difference in real use. And all the personal language and culture study experiences could be used as teaching materials, and the lecturer could incorporate personal language and culture study experience in teaching to facilitate and suggest the student's English language and culture learning.

... They can give more and better example, to help us to know what kind of language expression is better than we learned from text book...

... they can understand English in a real use, they can earn more experiences during study... 
...they know how to correct the language mistakes in real use...

... The lecturer can use their own experience as a raw teaching material...

... can give me more advice on English study, or even of I want to study abroad...

... can provide us more practical language usage, and for our students, it's a good

language learning resource...

... can give us more interesting and useful learning materials, and they may various they teaching material either and to be more flexible...

... they can use different teaching methods to inspire us and to lead us to know more new things, this may influence my study in the future...

Expectation 2: Facilitate in cross-culture communication

Students also accepted that the foreign-experienced lecturer may help the students create an effective English learning cultural context in the class. Since the lecturers experienced practically in both language use and culture, which enhanced them equipped with academic language knowledge and comprehensive culture understandings. The lecturers engaged themselves into a real English using environment, and experienced culture differences. Therefore, students insisted that the lecturers may facilitate their crossculture communication.

... we can learn both language points and cultural experiences from linguaculture experienced teacher...

... their experiences are real, they understand language and culture better than students...

... they can give our students more resources or suggestions in English learning, and English culture communication...

... they may have some more international and foreignized idea on Chinese culture...

... they experienced more and understand better on both language and culture could provide us broad teaching and learning content...

... I think they may motivate my language learning, especially English learning...

... the cultural context helps them to use language in a half real language and culture context...

- $\quad$ Students' concerns and suggestions

students concern on the lecturer's quality, no matter the lecturer is foreign-experienced or not, they concern on how qualified the lecturers are and the personal teaching ability. While, the students also concern on the subjects. They worried about some of the linguaculture experienced lecturers may not suitable for some course since the lecturer has been influenced by linguaculture, it may affect the lecturer understand the course correctly and sufficiently. Moreover, some of the students also concern on the conflict between the lecturers' teaching method and the students' language proficiency, learning method. Therefore, students suggested those foreign-experienced lecturers had better to adjust their experiences to meet the students' language competence and learning behaviors.

Concerns on: the lecturers' teaching experience and quality

... I want to say is the teacher's teaching and language quality, I think the teacher also need to be qualified...

... their linguaculture experience is great, but I am not sure whether the real teaching method and teaching experience they have or not...

... if the overseas experienced teacher without any innovation after they back to teach

in China, it's not so good...

Concerns on: the course

... But I think if some courses like Chinese culture, the linguaculture experienced lecturers may not really understand well...

... they were used to adjust themselves into foreign teaching and learning methods. When they backed to teaching in here, students' learning method and behavior is different, they may can really understand the teacher at first time..

Suggestions:

... but when they back to China, they have to adjust their linguaculture experiences to the English learning and teaching environment in China...

... they have to adjust themselves to our English learning and teaching to cope with our students' language competence in here, that's would be perfect...

... if they just back to teach at our university, it is better for them to adjust their learning, experience into teaching in here...

... But I think they may adjust their teaching a little bit in case we cannot catch them, 
because I am afraid of my English is not good enough... ... they may take time to get along with our learning behaviors in here, because they spend time on language study in foreign countries, so their learning behaviors may different from us...

The students suggested that the lecturer would better to adjust their linguaculture experiences to the Chinese class. Since the lecturer more or less has been influenced linguaculture study at abroad, therefore, the adjustments may cope with the students' English learning and teaching environment in China. The lecturer would better consider their linguaculture experience is understood by the students or not. Therefore, the individual English language proficiency should be considered when the lecturers incorporate their linguaculture experiences in English class. It a suggestion for the lecturer to re-think about their teaching, and how to make the learning more effective by incorporating linguaculture experience. To make them rethink that the whether the linguaculture experience is beneficial for the Chinese students as Chuxiong normal university or not.

\section{Summary and conclusion}

This study was attempted to define what linguistic and culture aspects had been influenced by the lecturers' foreign study experiences. Meanwhile, with the aim to explore the students' attitude towards the lecturers who were equipped with foreign study experiences. Under the inseparable relationship between language culture (Scollon, 2012), to strengthen English learners' understanding of the language and improve their English language competence in cross-culture communication, cultivating cross-culture awareness in necessary. Therefore, English lecturer's language and culture background affected the learner's linguistic practice and linguistic resource (Pan, 2015).

In this study, it generally defined that lecturer's overseas language and culture study experience impressed them indeed, which presented into four ways, language and culture teaching methods, language and culture learning behaviors, cross-culture awareness and communication, and function of English language. These fours impressive affected and innovated the lecturers when they backed to teaching in Chuxiong Normal University. From the finding, which explained that the teaching methods and skills, teaching concept had been innovated. And also, the lecturer personally concerns on the students' language competence and proficiency in practical. Students' attitude also positively explained they were expected to learn with these foreign- experienced lecturers, since they insisted that the foreign- experienced lecturers would facilitate them in linguistic practice and cross-culture communication. Moreover, the students presented concerns on lecturers teaching experience, course, and eventually suggested the lecturer to balance their personal overseas language and culture study experience and language teaching in real.

\subsection{Recommendations}

Based on the findings presented in the study, due to the communicative role of language in communication classroom, which requires lecturers are well equipped with both language proficiency and intercultural awareness. Therefore, initially this study may suggest the way in teaching. The English language lecturer had better concern on the students' English learning behavior, to observe and define students' English learning behaviors in the class individually. Meanwhile, this study also suggested foreign-experienced lecturers adjust and balance their personal language and culture learning experience in practical teaching in the class. Only if both the lecturer and students incorporate with each other appropriately in class, teaching could be achieved successfully.

\section{Reference}

Agar, M. (1994)) Language shock: understanding the culture of conversation. New York, Perennial. US.

Creswell, J.W. (2003) Research design, qualitative, quantitative, and mixed methods approaches $\left(2^{\text {nd }}\right)$. Sage Publications. CA, US.

Creswell, J.W. (2007) Qualitative inquiry, research design (2 $\left.{ }^{\text {nd }}\right)$. Sage Publications. CA, US.

Creswell, J.W. (2002) Educational research, planning, conducting, and evaluating qualitative and quantitative research. Pearson Education. NJ. US.

Crystal, D. (1997) English as a global language. London, Cambridge University press. UK.

Dervin, F. \& Liddicoat, A.J. (2013) Linguistics for intercultural education. John Benjamins Publishing Company, USA.

Fiorin, G. \&Delfitto, D. (2020) Beyond Meaning: A journey across language, perception and experience. Springer, Switzerland.

Fromkim, V., Rodman, R. \&Hyams, N. (2017) An introduction to language. Cengage Learning Inc., USA.

Genter, M.T. (2014) Teaching English to Thai learner. Bangkok University Press. TH.

Halliday, M.A.K. (2003) On language and linguistics. Continuum, USA.

Hall, G. (2011) Exploring English language teaching, language in action. Routledge Tylor \& Francis Group. NY Huang Zheng. (2017) Native and non-native English speaking teachers in China, perceptions and practice. 
Springer, UK.

Jackson, J. (2012). The Routledge handbook of language and intercultural communication. Routledge Tylor \& Francis Group. NY

Kramsch, C. (2008) 'ecological perspectives on foreign language education'. Language teaching 41:389-408

Kachru, B.B., Kachru, Y. \& Nelson C.L. (2006) The handbook of world Englishes. Blackwell Publishing Ltd. USA.

Liddicoat, A. J. \& Scarino, A. (2013). Intercultural language teaching and learning. Wiley- Blackwell. OX, UK. Merriam, S., Tisdell, E.J. (2016) Qualitative research, a guide to design and implementation. John Wiley\& Sons, Inc. US.

Nieto, S. (2010). Language, culture, and teaching, critical perspectives $\left(2^{\text {nd }}\right)$. Routledge Tylor \& Francis Group. NY

Lin Pan (2015) English as a global language in China. Springer International Publishing. UK.

Scollon, R., Scollon, S. W., \& Jones, R. H.. (2012) Intercultural communication, a discourse approach $\left(3^{\text {rd }}\right)$. Blackwell Publishing Ltd. UK.

Sharifian, F. \& Palmer, G.B. (2007) Applied cultural linguistic. John Benjamins Publishing Company, USA.

Impressive influential aspects

- language and culture teaching methods

- language and culture learning behaviors

- cross-culture awareness and communication

- function of English language

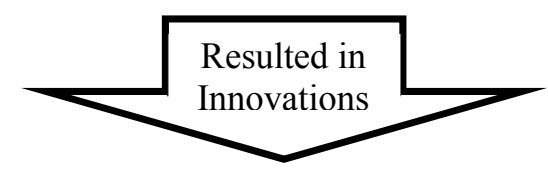

- Teaching concept

- Teaching methods and skills

- Teaching concerns

Figure 1 Influential Factors from the Lecturers' Interview 